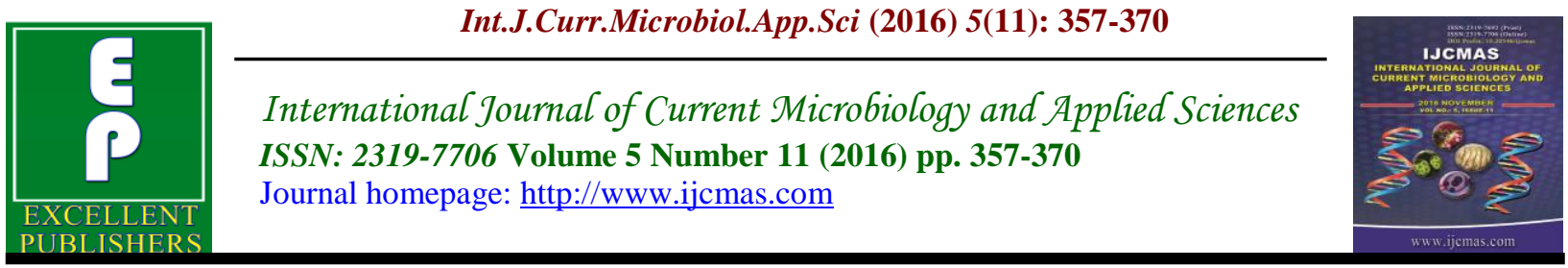

Original Research Article

http://dx.doi.org/10.20546/ijcmas.2016.511.041

\title{
Phylogenetic Diversity of Bacterial Communities of Western India Oil Fields by PCR-DGGE
}

\author{
Mahesh Chitrakoti $^{1 *}$ and Kalpana Chandramore ${ }^{2}$ \\ ${ }^{1}$ Vidya Pratishthan's School of Biotechnology, Baramati, India \\ ${ }^{2}$ Vidya Pratishthan's Arts, Science and Commerce College, Baramati, India \\ *Corresponding author
}

\section{Keywords \\ Bacterial community, DGGE, Indian oil reservoirs, Phylogenetic analysis.}

\section{Article Info}

Accepted:

16 October 2016

Available Online:

10 November 2016

\section{A B S T R A C T}

The diversity of bacterial communities in the formation waters of ten oil reservoirs from western India was analyzed by PCR - Denaturing Gradient Gel Electrophoresis (DGGE). 16S rRNA gene fragments of the bacterial community were PCR amplified using universal primers targeting V3-V5 eubacterial hypervariable regions. The phylogenetic analysis revealed that formation water metagenome mainly constituted bacteria, showing similarity to Paracoccus, Brachymonas, Hydrogenophaga, Bacillus, Pelomonas, Thalasospira and Pseudomonas. Many of the bacterial sequences shared less than $95 \%$ homology with the reference sequences available in Gen-Bank database, hence; some of these could represent novel species/ genera. Application of statistical indices such as Simpson's index (1- D) and the Shannon-Weaver index $(H)$ to the well resolved DGGE pattern of $16 \mathrm{~S}$ rR NA gene fragments revealed more diversity of bacteria in S7 and S9 samples, whereas equitability (J) data indicated that population was not dominated by any species. It was also observed that formation water consisted of predominantly the proteobacteria capable of nitrate reduction and hydrocarbon degradation.

\section{Introduction}

Petroleum biotechnology is a very young and exciting field for the possible applications in industrial point of view. It is well-known that petroleum reservoirs contain active and diverse populations of microorganisms and their growth within oil reservoirs has usually been associated with biofouling and souring. The studies are going on to create a resource base for new genetic information achieved from the microorganisms in the reservoir. Microorganisms from the oil reservoirs can be used in the areas like exploration and production of oil as well as biological upgradation of oil to improve quality. Extremophiles from oil reservoirs may have new thermophilic and piezophilic enzyme system which can enable new bioengineering processes and products for the oil exploration and production (Kotlar et al., 2004).

Formation water occurs naturally within pores of rock. There is a variation observed 
in formation water composition from one reservoir to another and also within reservoirs. The possibility for living organisms to survive in oil reservoir environments depends on the physical characteristics and chemical composition of the ecosystem. Temperature is the most important limiting factor for microbial growth in oil reservoirs (Magot et al., 2000). Oil reservoirs harbor a wide variety of microorganisms. The study of these microorganisms is important as they may have potential to affect oil quality and geological properties of the reservoir. Oil reservoir is a distinctive habitat with astonishing diversity of microbial populations and communities. Microorganisms from petroleum reservoirs having hydrocarbon metabolizing ability play an important role in their possible industrial application such as microbial enhanced oil recovery (Wang et al., 2008). Molecular techniques like 16S rRNA gene sequence analysis, restriction fragment length polymorphism (RFLP), reverse sample genome probing and oligonucleotide matrix array hybridization methods have been used extensively to study microbial diversity from oil reservoirs. PCR based finger printing technique, denaturing gradient gel electrophoresis (DGGE) is less labour-intensive approach has been used to investigate the bacterial diversity of soils and aquatic environments (Schafer and Muyzer, 2001). Such diversity studies have been done for the characterization of oil reservoirs having high temperature in Western Siberia, Russia (BonchOsmolovskaya et al., 2003), biodegraded petroleum reservoir having low temperature and low salinity from a Western Canadian Sedimentary Basin (Grabowski et al., 2005), water flooded oil reservoirs from western Canadian harboring reservoir (Voordouw et al., 1992, 1996); oil reservoirs from a southern offshore Brazilian basin (Sette et al., 2007) etc. Many microorganisms isolated from oil reservoirs are able to produce biosurfactants (Bryant and Douglas, 1988; Margaritis et al., 1979) and biopolymers (Kalish et al., 1964). These microorganisms are of interest in microbially enhanced oil recovery (MEOR). Therefore, it is of great interest to study microbial diversity of oil reservoirs for the exploitation of native bacteria with their positive effects (Kaster et al., 2009).

Microbial communities from Indian oil reservoirs have been less studied. While India has significant reserves of coal, it is relatively poor in oil and gas resources. The petroleum reserves of India, situated in Gujarat, Bombay High (next to the seashore of Maharashtra), eastern Assam, and Rajasthan, satisfy about $1 / 4^{\text {th }}$ of the requirements of the nation. Its oil reserves amount to 5.9 billion barrels, $(0.5 \%$ of global reserves) with total proven, probable, and possible reserves of close to 11 billion barrels (http://petroleum.nic.in). The purpose of this study was to reveal the diversity of bacteria from western India oil well formation waters by culture independent approach. 16S rDNA based PCR-DGGE technique is used for phylogenetic analysis. This study is expected to elucidate the bacterial taxonomic picture in poorly studied Indian oil reservoirs.

\section{Materials and Methods}

\section{Sample collection}

Formation water samples were collected from oil reservoirs located at Gujarat state of India from 850-1500m depth. Samples from ten different oil wells were collected in sterile poly propylene containers. Temperature and $\mathrm{pH}$ of the samples were recorded at the collection point. Samples 
were immediately transferred to $4^{\circ} \mathrm{C}$ and preserved until further use.

\section{Physico-chemical analysis of formation water}

The parameters like total solids (TS), volatile solids (VS), total nitrogen (TN), ammoniacal nitrogen (TAN), heavy metal ion content of all formation water samples were determined according to standard methods (Eaton et al., 2005).

\section{Extraction of nucleic acids from formation water}

The metagenomic DNA from the formation water was extracted by CTAB method (Zhou et al., 1996). Bacterial biomass was harvested from $25 \mathrm{ml}$ formation water sample by centrifugation at $12,000 \mathrm{x} \mathrm{g}$ for 10 minutes and used for DNA isolation instead of $5 \mathrm{~g}$ soil samples as described in the original method. The nucleic acid pellet was washed with cold $70 \%$ ethanol, and resuspended in sterile deionized water, to give a final volume of $40 \mu \mathrm{l}$.

\section{Polymerase chain reaction for amplification of 16S rRNA gene}

Nested PCR was performed to amplify V3$\mathrm{V} 5$ region of $16 \mathrm{~S}$ rDNA using universal primers (Rawlings, 1995; Muyzer et al., 1993; Schwieger and Tebbe, 1998). PCR amplification was performed in a $50 \mu \mathrm{l}$ PCR mixture containing $1.5 \mathrm{U}$ Taq DNA polymerase, 10x buffer, 50 pmol of each primer, and $200 \mu \mathrm{M}$ dNTP. PCR primers are listed in Table 1. PCR amplifications were performed in Mastercycler Gradient Thermal Cycler (Eppendorff, Germany) under the conditions of initial denaturation at $95^{\circ} \mathrm{C}$ for $5 \mathrm{~min}, 35$ cycles of $94^{\circ} \mathrm{C}$ for 1 min, annealing at $60^{\circ} \mathrm{C}$ for $1 \mathrm{~min}$ with bacterial primers and extension at $72^{\circ} \mathrm{C}$ for 1 min with a final elongation step of $72^{\circ} \mathrm{C}$ for 5 min. The resulting 16S rRNA gene amplicons were purified using polyethylene glycol precipitation (Sambrook and Russel, 2001). The outer PCR was performed using FDD2-RPP2 primer pair whereas nested PCR was carried out using SRV3-1 and COM-2 primers. A 40 bp GC clamp was attached to the 5' end of the SRV3-1 primer (Wang et al., 2008; Ferris et al., 1996; Grabowski et al, 2005). The PCR products were validated by agarose gel electrophoresis and then purified to eliminate the ssDNA and heteroduplexes (Wang et al., 2008).

\section{DGGE}

DGGE analysis of the amplified sequences was performed on 16 x $16 \mathrm{~cm}$., 6\% polyacrylamide gels with a denaturing gradient of 40 to $60 \%$ (100\% denaturants gels defined as $7 \mathrm{M}$ urea and $40 \%$ deionized formamide). The PCR amplicons (200ng) were loaded in each well and electrophoresis was performed at a constant voltage of $130 \mathrm{~V}$ for $200 \mathrm{~min}$ at $60^{\circ} \mathrm{C}$ for $7 \mathrm{hrs}$ in the DGGE tank (Biorad, USA). Gels were stained with ethidium bromide solution $(0.5 \mu \mathrm{g} / \mathrm{ml})$ for 15 min, washed with distilled water and visualized by U.V. transillumination (AlphaImager, Alpha Innotech, USA).

\section{Sequencing of DGGE bands}

DGGE bands were excised from the gels and DNA was eluted in deionized distilled water. The fragments were reamplified with the SRV3-1 primers without GC clamp and purified by polyethylene glycol (PEG 6000, $8 \%$ ) precipitation (Sambrook and Russel, 2001). The eluted DNA fragments were reamplified using the set of corresponding primers. Purified PCR product was then used as template for cycle sequencing reaction using $\mathrm{COM}-2$ primer and $\mathrm{ABI}$ 
Prism Big Dye Terminator Cycle Sequencing Ready Reaction kit (Applied Biosystem, Foster City, CA, USA). Post cycle sequencing clean-up was done by Big Dye Clean Up method, according to the manufacturer's instructions (Invitrogen, India) and subjected to sequencing in an automated sequencer (3100 Avant Gene Analyser, Applied Biosciences, USA). The sequencing output was analyzed using the accompanying DNA Sequence Analyzer computer software (Applied Biosystems).

\section{Sequences analysis}

Sequences that differed by less than 3\% were considered to belong to the same phylotype (Stackbrandt and Goebel, 1994) and each phylotype was represented by a sequence type. This sequence was compared with reference sequences available in the GenBank database using the BLAST algorithm to establish phylogenetic affiliation. Sequences alignments were performed using the software CLUSTAL W (http://www.ebi.ac.uk/) (Thompson et al., 1997). Software Mega 5.0 was employed to construct the phylogenetic tree based on Kimura two-parameter model (Kimura, 1980) and neighbor-joining algorithm (Saitou and Nei, 1987). Bootstrap analysis with 1,100 replicated was applied to assign confidence levels to the nodes in the trees.

\section{Diversity Indices}

DGGE profiles were statistically analysed and compared using a set of diversity indices. Gels were normalized by eliminating bands with peak height intensity of less than $2 \%$ of the most intense band in each lane as background noise. Alpha Imager software (Alpha Innotech, USA) was used to extract this information. Each band was considered as an independent OTU (Operational Taxonomic Unit) and the intensity of the bands measured in pixels was considered as population size. The diversity and relationship between the band patterns obtained in this study within the bacterial communities were evaluated by several species diversity indices (Atlas and Bartha, 1998). Here, Simpson's index $(D=$ sum $\left.\left[P i^{2}\right]\right)$ was used, where pi is the proportion of total intensity of the $i^{\text {th }}$ band. Along with this, Simpson's index of diversity (1 - D); Simpson's reciprocal index (1/D); Shannon-Weaver index $(\mathrm{H}=-$ sum $(\mathrm{Pi}$ ln [Pi]); Equitability index ( $\mathrm{J}=\mathrm{H} / \mathrm{Hmax})$, where $H_{\max }$ is the theoretical maximal $\mathrm{H}$ for the population examined, assuming each species has only one number were also used for diversity analysis.

\section{Results and Discussion}

\section{Physico-chemical analysis of formation Water}

In the present study detailed analysis of all formation water samples was carried out. It is observed that the total solid (TS) content in all formation water samples was in the range of $0.85-0.89 \mathrm{~g} \%$. TS contribute the total suspended and total dissolved solids. The volatile solids (VS) contribute the organic matter which acts as a substrate for native microorganisms. The percentage of $\mathrm{VS}$ in all samples is less than $0.03 \mathrm{~g} \mathrm{\%}$, which was very low to support the growth of the bacteria. Formation water is associated with crude oil in the reservoir. Therefore native bacteria may have developed metabolic potential to use hydrocarbons as a substrate in oil reservoirs. The $\mathrm{pH}$ of all formation water samples was slightly alkaline and salinity (\% of $\mathrm{NaCl}$ ) was near one percent (Table 2). The concentrations of $\mathrm{Cu}$ were found to be in the range of 0.08-0.3 $\mathrm{ppb}$ which is below the inhibitory concentration required for microorganisms (Ochoa-Herrera et al., 2011). MIC of Cd for 
Bacteria like Pseudomonas sp., Bacillus sp., Staphylococcus $s p$. was reported to be higher than $799 \mathrm{mg} / \mathrm{L}$ (Nath et al., 2012). The cadmium concentration in all the formation water sample is in the range of 0.01-0.22 $\mathrm{mg} / \mathrm{L}$. The heavy metals like $\mathrm{Hg}$, $\mathrm{Pb}$ and $\mathrm{As}$ were not detected in any of the sample tested. The concentration of total nitrogen (Kjeldahl nitrogen) as well as ammoniacal nitrogen was not more than 55 $\mathrm{ppm}$, indicating nitrogen deficiency in any of the samples tested (Table 3). The physico-chemical analysis revealed that formation water is not inhibitory for the growth of the native bacteria.

\section{Separation of PCR products by DGGE}

The DNA of ten formation water samples was extracted with CTAB method. Even though the samples were collected from the nearby fields, in DGGE distinctly different gel pattern was observed. The pattern of bands in DGGE gel showed good resolution and separation (Fig.1). Total 36 bands were separated and after elution of each band, they were reamplified in PCR using SRV3-1 and $\mathrm{COM}-2$ primers.

\section{Nucleotide sequence accession numbers}

The nucleotide sequences reported in this paper have been deposited in the NCBI nucleotide sequence databases under accession numbers JX036286 to JX036321.

\section{Diversity indices}

Diversity indices calculated using band intensities of the DGGE profiles indicated that the bacterial diversity is more in S7 and S9. Simpson's reciprocal index (1/D) and the Shannon-Weaver index (H) revealed more diversity in these samples. To quantitatively measure diversity in the ten different samples, Simpson's reciprocal index (1/D) was used, which is sensitive to the level of dominance in community. It ensures that an increase in the reciprocal index reflects an increase in diversity. Simpson's index of diversity $(1-\mathrm{D})$ measures the probability that two individuals randomly selected from a sample will belong to the same species. Therefore more is the 1-D value, more is the diversity. Samples S6 and S2 were shown relatively low values of Simpson's reciprocal index (1/D), indicating less diversity in the formation water samples. The equitability (J) data indicated that there is less variation in the communities in any of the formation water tested (Table 4).

\section{Analysis of bacterial community profile revealed in DGGE}

In the DGGE, band pattern with GC Clamp and COM-2 from all the DNA samples, representatives of bands that were clear and had high intensity were excised from polyacrylamide gel. They were reamplified and subjected to sequencing. The sequences of a total of 36 DNA fragments were successfully determined. The formation of chimeric DNA fragments was not observed in those sequences. The phylogenetic relationships of the 36 sequenced bands are shown in Fig. 2.

All bands were separated into two major groups, proteobacteria and firmicutes. The total 36 sequences assigned to the 24 distinct phylogenetic groups which clustered among Firmicutes (10 sequenecs), Proteobacteria (22 sequences), Actinobacteria (3 sequences) and Bacteriodetes (1 sequence). The samples of formation water appears to harbor unique microbial communities as many of the sequences had less than or equal to $95 \%$ identity to closest matches in the GeneBank and probably represent novel genera or species. Most bacteria detected in 
the PCR-DGGE library cluster are among the fermentative organisms. The ten sequences that cluster within the firmicutes lineage, indicate the presence of a large fraction of highly diverse Gram positive organisms (Table 5; Fig. 2).

It was significant that a number of bands related to hydrocarbon-degrading strains have been reported previously from oil wells and oil-contaminated soil samples. Cyclohexane degrading Brachymonas petroleovorans was previously isolated from oil refinery wastewater sludge, (Rouviere and Chen, 2003), Chryseobacterium sp. was reported as PAH degrading bacteria by Kumar et al., (2011) and Guo et al., (2008). Pelobacter carbinolicus has been detected in the clone library obtained from produced water from a high-temperature North Sea oil-field (Dahle et al., 2008). Species of the Bacillus has been reported as candidate for hydrocarbon degradation. Ahlam AlSharidah et al., (2000), used crude oil degrading Bacillus subtilis for hydrocarbon degradation studies. Hydrocarbon degrading Aeribacillus pallidus strain MCM B-882 from western India oil reservoirs was isolated and characterized by Chitrakoti (2016). Eighteen spore-forming grampositive bacteria were isolated from an oil reservoir located in a deep-water production basin in Brazil by Cunha et al., (2006). Fusibacter paucivorans was isolated from an African saline oil-producing well (Ravot et al., 1999).

Table.1 Primers used for the amplification of 16S rRNA gene

\begin{tabular}{|l|l|l|l|}
\hline Primer & Position* & Sequence & Reference \\
\hline FDD2 (F) & $8-27$ & $\begin{array}{l}\text { 5'CCGGATCCGTCGACAGAGTTTGATCIT } \\
\text { GGCTCAG 3' }\end{array}$ & $\begin{array}{l}\text { Rawlings } \text { et al } \\
\text { (1995) }\end{array}$ \\
\hline RPP2 (R) & $1473-1503$ & $\begin{array}{l}\text { 5'CCAAGCTTCTAGACGGITACCTTGTTA } \\
\text { CGACTT 3' }\end{array}$ & $\begin{array}{l}\text { Rawlings } \text { et al } \\
\text { (1995) }\end{array}$ \\
\hline $\begin{array}{l}\text { GC Clamp- } \\
\text { SRV3-1 (F) }\end{array}$ & $514-533$ & $\begin{array}{l}\text { 5'CGCCCGCCGCGCGCGGCGGGCGGGGC } \\
\text { GGGGGCACGGGGGGGCTACGGGAGGC } \\
\text { AGCAG 3' }\end{array}$ & $\begin{array}{l}\text { Muyzer } \text { et al., } \\
\text { (1993) }\end{array}$ \\
\hline COM-2 (R) & $907-926$ & 5'CCGTCAATTCCTTTGAGTTT 3' & $\begin{array}{l}\text { Schwieger and } \\
\text { Tebbe (1998) }\end{array}$ \\
\hline
\end{tabular}

*Positions of primers corresponding to $E$. coli $16 \mathrm{~S}$ rDNA

Table. $2 \mathrm{pH}$, salinity and organic matter content of formation water samples

\begin{tabular}{|l|l|l|l|l|}
\hline Sample & TS $(\mathbf{g}$ \%) & VS $(\mathbf{g}$ \%) & $\mathbf{p H}$ & Salinity (\%) \\
\hline S1 & 0.89 & 0.012 & 7.82 & 0.89 \\
\hline S2 & 0.88 & 0.013 & 8.01 & 0.88 \\
\hline S3 & 0.86 & 0.013 & 8.00 & 0.87 \\
\hline S4 & 0.86 & 0.014 & 8.00 & 0.86 \\
\hline S5 & 0.87 & 0.010 & 8.20 & 0.87 \\
\hline S6 & 0.88 & 0.028 & 8.01 & 0.88 \\
\hline S7 & 0.86 & 0.020 & 8.02 & 0.86 \\
\hline S8 & 0.86 & 0.012 & 8.00 & 0.86 \\
\hline S9 & 0.85 & 0.024 & 8.01 & 0.85 \\
\hline S10 & 0.86 & 0.021 & 8.01 & 0.86 \\
\hline
\end{tabular}


Table.3 Nitrogen and heavy metal ion content of formation water samples

\begin{tabular}{|c|c|c|c|c|c|c|c|}
\hline \multirow{2}{*}{ Sample } & \multicolumn{6}{|c|}{ Concentration in ppm } & \multicolumn{6}{l|}{ Concentration in ppb } \\
\cline { 2 - 8 } & Total N & Ammonical N & Cu & Cd & Pb & As & Hg \\
\hline S1 & 44.06 & 55.00 & 0.08 & 0.14 & ND & ND & ND \\
\hline S2 & 34.59 & 42.00 & 0.08 & 0.01 & ND & ND & ND \\
\hline S3 & 32.54 & 40.00 & 0.18 & 0.08 & ND & ND & ND \\
\hline S4 & 38.38 & 50.00 & 0.10 & 0.80 & ND & ND & ND \\
\hline S5 & 34.92 & 41.00 & 0.08 & 0.09 & ND & ND & ND \\
\hline S6 & 37.30 & 45.00 & 0.06 & 0.22 & ND & ND & ND \\
\hline S7 & 19.68 & 26.00 & 0.15 & 0.09 & ND & ND & ND \\
\hline S8 & 38.59 & 48.00 & 0.29 & 0.08 & ND & ND & ND \\
\hline S9 & 26.00 & 48.11 & 0.07 & 0.09 & ND & ND & ND \\
\hline S10 & 35.68 & 44.00 & 0.13 & 0.08 & ND & ND & ND \\
\hline
\end{tabular}

ND- Not detected

Table.4 Diversity indices to analyze bacterial community data in oil reservoirs

\begin{tabular}{|c|c|c|c|c|c|}
\hline Sample & D & 1-D & 1/D & H & J \\
\hline S1 & 0.14 & 0.86 & 7.14 & 2.28 & 0.84 \\
\hline S2 & 0.43 & 0.62 & 2.32 & 2.34 & 0.84 \\
\hline S3 & 0.24 & 0.76 & 4.16 & 1.80 & 0.75 \\
\hline S4 & 0.20 & 0.80 & 5.00 & 1.75 & 0.90 \\
\hline S5 & 0.17 & 0.83 & 5.88 & 2.35 & 0.74 \\
\hline S6 & 0.45 & 0.55 & 2.22 & 2.22 & 0.84 \\
\hline S7 & 0.09 & 0.91 & 10.86 & 2.59 & 0.88 \\
\hline S8 & 0.12 & 0.88 & 8.33 & 2.27 & 0.86 \\
\hline S9 & 0.10 & 0.90 & 10.10 & 2.53 & 0.87 \\
\hline S10 & 0.12 & 0.88 & 8.06 & 2.39 & 0.83 \\
\hline
\end{tabular}

Table.5 Identification of 16S rRNA gene sequences from bacterial communities of formation water samples

\begin{tabular}{|c|c|c|c|}
\hline Sample & $\begin{array}{l}\text { DGGE band code } \\
\text { (accession no.) }\end{array}$ & $\begin{array}{l}\text { Closest cultivable species } \\
\text { (\% identity) [accession no] }\end{array}$ & $\begin{array}{l}\text { Maximum identity to GenBank (\% } \\
\text { identity) [accession no.] }\end{array}$ \\
\hline \multirow[t]{2}{*}{$\mathrm{S} 1$} & H1(JX036286) & $\begin{array}{c}\text { Pelobacter carbinolicus }(97) \\
{[\text { [NC007498.2] }}\end{array}$ & $\begin{array}{c}\text { Pelobacter carbinolicus }(97) \\
{[\mathrm{NC} 007498.2]}\end{array}$ \\
\hline & H2 (JX036287) & $\begin{array}{c}\text { Fusibacter paucivorans (96) } \\
\text { [NR024886.1] }\end{array}$ & $\begin{array}{c}\text { Fusibacter paucivorans (96) } \\
\text { (NR024886.1) }\end{array}$ \\
\hline \multirow[t]{2}{*}{$\mathrm{S} 2$} & F1 (JX036288) & $\begin{array}{c}\text { Brachymonas petroleovorans (97) } \\
\text { [AY275432.1] }\end{array}$ & $\begin{array}{c}\text { Uncultured bacterium (97) } \\
\text { (FN4294OO.1) }\end{array}$ \\
\hline & F2 (JX036289) & $\begin{array}{c}\text { Hydrogenophaga sp. }(98) \\
\text { [AB681449.1] }\end{array}$ & $\begin{array}{c}\text { Uncultured bacterium (99) } \\
\text { [EF459884.1] }\end{array}$ \\
\hline \multirow[t]{3}{*}{ S3 } & 1a (JX036290) & $\begin{array}{l}\text { Hydrogenophaga sp. (97) } \\
\text { [EF179863.1] }\end{array}$ & $\begin{array}{c}\text { Uncultured bacterium (99) } \\
\text { [EF459884.1] }\end{array}$ \\
\hline & 1b (JX036291) & $\begin{array}{c}\text { Brachymonas petroleovorans } \\
\text { (94) [AY275432.1] }\end{array}$ & $\begin{array}{l}\text { Uncultured bacterium (95) } \\
\text { [FN429400.1] }\end{array}$ \\
\hline & 1c (JX036292) & $\begin{array}{c}\text { Nitrospira sp. }(97) \\
{[\text { AJ224041.1] }}\end{array}$ & $\begin{array}{c}\text { Uncultured bacterium (98) } \\
\text { [JQ003189.1] }\end{array}$ \\
\hline
\end{tabular}


Table.5 continued..

\begin{tabular}{|c|c|c|c|}
\hline Sample & $\begin{array}{l}\text { DGGE band code } \\
\text { (accession no.) }\end{array}$ & $\begin{array}{l}\text { Closest cultivable species } \\
(\% \text { identity) [accession no] }\end{array}$ & $\begin{array}{l}\text { Maximum identity to GenBank } \\
\text { (\% identity) [accession no.] }\end{array}$ \\
\hline \multirow[t]{4}{*}{ S4 } & M1 (JX036293) & Bacillus thioparans (97) [JN999834.1] & $\begin{array}{c}\text { Bacillus thioparans }(97) \\
{[\mathrm{JN} 999834.1]}\end{array}$ \\
\hline & M2 (JX036294) & Thalassospira sp. (99) [EU440812.1] & Thalassospira sp. (99) [EU440812.1] \\
\hline & M3 (JX036295) & Thalassospira sp. (92) [EU440812.1] & Thalassospira sp. (92) [EU440812.1] \\
\hline & M4 (JX036296) & Thalassospira sp. (99) [EU440812.1] & Thalassospira sp. (99) [EU440812.1] \\
\hline \multirow[t]{4}{*}{ S5 } & C1 (JX036297) & $\begin{array}{c}\text { Sphingomonas panni }(97) \\
{[\mathrm{HQ739092.1]}} \\
\end{array}$ & $\begin{array}{c}\text { Uncultured bacterium (97) } \\
{[\text { GQ158668.1] }}\end{array}$ \\
\hline & C2 (JX036298) & $\begin{array}{c}\text { Paracoccus sp. (99) } \\
{[681877.1]}\end{array}$ & $\begin{array}{c}\text { Paracoccus sp. (99) } \\
{[681877.1]}\end{array}$ \\
\hline & C3 (JX036299) & $\begin{array}{c}\text { Paracoccus pantotrophus }(96) \\
\text { [JQ246875.1] }\end{array}$ & $\begin{array}{c}\text { Uncultured bacterium (96) } \\
{[\mathrm{JF} 189197.1]}\end{array}$ \\
\hline & C4 (JX036300) & Paracoccus sp. (99) [JN681877.1] & Paracoccus sp. (99) [JN681877.1] \\
\hline \multirow[t]{4}{*}{ S6 } & A1 (JX036301) & $\begin{array}{l}\text { Brachymonas petroleovorans (97) } \\
\text { [AY275432.1] }\end{array}$ & Uncultured bacterium (98) [EF459884.1] \\
\hline & A2 (JX036302) & $\begin{array}{c}\text { Sulfurospirillum sp. (94) } \\
\text { [AF357199.1] }\end{array}$ & Uncultured bacterium (98) [ [FJ469320.1] \\
\hline & A3 (JX036303) & Pelomonas puraquae (94) [JQ660112.1] & Uncultured bacterium (95) [AB240287.1] \\
\hline & A4 (JX036304) & Thauera sp. (97) [AY570693.1] & $\begin{array}{c}\text { Uncultured Thauera sp. (97) } \\
(\text { JN648270.1) }\end{array}$ \\
\hline \multirow[t]{4}{*}{ S7 } & a1 (JX036305) & $\begin{array}{c}\text { Pelomonas saccharophila }(90) \\
\text { [AB681917.1] }\end{array}$ & Uncultured bacterium (91) [AB240287.1] \\
\hline & a2 (JX036306) & $\begin{array}{c}\text { Pelomonas puraquae }(93) \\
\text { [JQ660112.1] }\end{array}$ & Uncultured bacterium (91) [AB240287.1] \\
\hline & a3 (JX036307) & Paracoccus sp. (99) [JQ691539.1] & Uncultured bacterium (99) [HM314606.1] \\
\hline & a4 (JX036308) & $\begin{array}{c}\text { Propionibacterium sp. (99) } \\
\text { [AB084066.1] }\end{array}$ & Uncultured organism (99) [HQ749197.1] \\
\hline \multirow[t]{5}{*}{ S8 } & b1 (JX036309) & Paracoccus sp. (99) [JQ691539.1] & Paracoccus sp. (99) [JQ691539.1] \\
\hline & b2 (JX036310) & Staphylococcus sp. (97) [JQ361085.1] & Uncultured bacterium (97) [JF199400.1] \\
\hline & b3 (JX036311) & Staphylococcus sp. (97) [JQ361085.1] & Uncultured bacterium (97) [JF199400.1] \\
\hline & b4 (JX036312) & $\begin{array}{c}\text { Thermoanaerobacter brockii (100) } \\
\text { [HE601764.1] }\end{array}$ & Uncultured bacterium (100) [JQ612532.1] \\
\hline & b5 (JX036313) & $\begin{array}{c}\text { Propionibacterium sp. (99) } \\
\text { [AB084066.1] }\end{array}$ & Uncultured organism (99) [HQ749197.1] \\
\hline \multirow[t]{4}{*}{ S9 } & c1 (JX036314) & Enterococcus sp. (94) [JQ028132.1] & Uncultured bacterium (95) [HM821143.1] \\
\hline & c2 (JX036315) & Bacillus sp. (98) [AY159884.1] & $\begin{array}{c}\text { Bacillaceae bacterium (98) } \\
{[\mathrm{DQ} 490410.1]}\end{array}$ \\
\hline & c3 (JX036316) & Bacillus circulans (95) [JQ246876.1] & Bacillus circulans (95) [JQ246876.1] \\
\hline & c4 (JX036317) & $\begin{array}{c}\text { Propionibacterium sp. (99) } \\
\text { [AB084066.1] }\end{array}$ & Uncultured bacterium (99) [JF185156.1] \\
\hline \multirow[t]{4}{*}{ S10 } & d1 (JX036318) & Chryseobacterium sp. (95) [HQ396899.1] & Chryseobacterium sp. (95) [HQ396899.1] \\
\hline & d2 (JX036319) & Uncultured bacterium (91) [JF208716.1] & Uncultured bacterium (91) [JF208716.1] \\
\hline & d3 (JX0363120) & Lysobacter sp. (97) [EU780693.1] & Uncultured bacterium (97) [DQ532277.1] \\
\hline & d4 (JX036309) & $\begin{array}{c}\text { Propionibacterium sp. (99) } \\
{[\mathrm{AB} 084066.1]}\end{array}$ & Uncultured organism (99) [HQ749197.1] \\
\hline
\end{tabular}


Fig.1 DGGE patterns of the PCR products amplified from primers GC Clamp and COM- 2. Lane 1- S1, Lane 2-S2, Lane 3-S3, Lane 4- S5, Lane 5- S4, Lane 6- S9, Lane 7-S10, Lane 8- S7, Lane9 -S8, Lane10 - S6
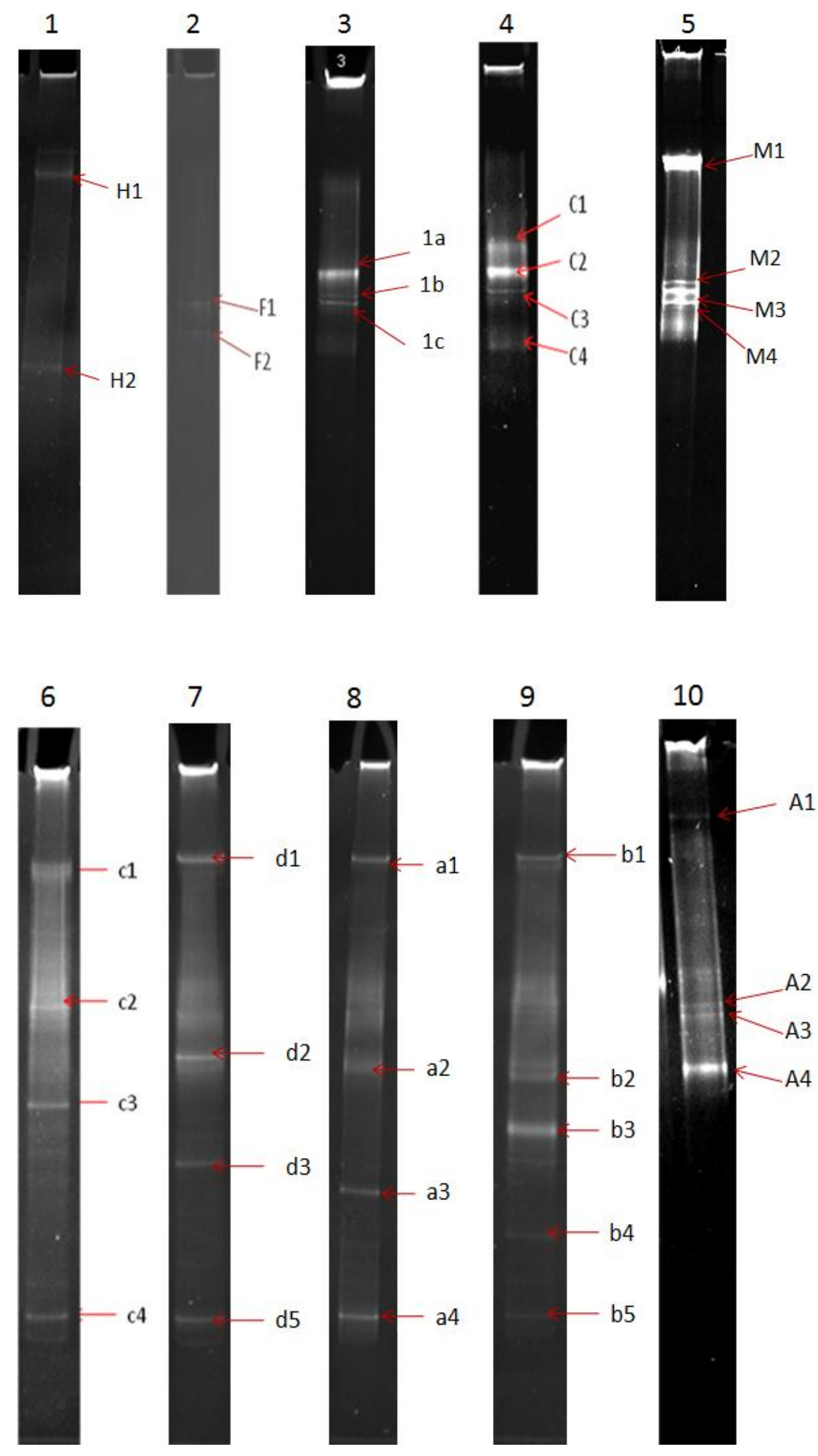
Fig.2 Phylogenetic tree demonstrating the relationship of the thirty six predominant band sequences based on 16S rRNA gene V3-V5 region from the petroleum reservoir with other sequences obtained from Blast searches. The scale bar represents number of substitutions per site.

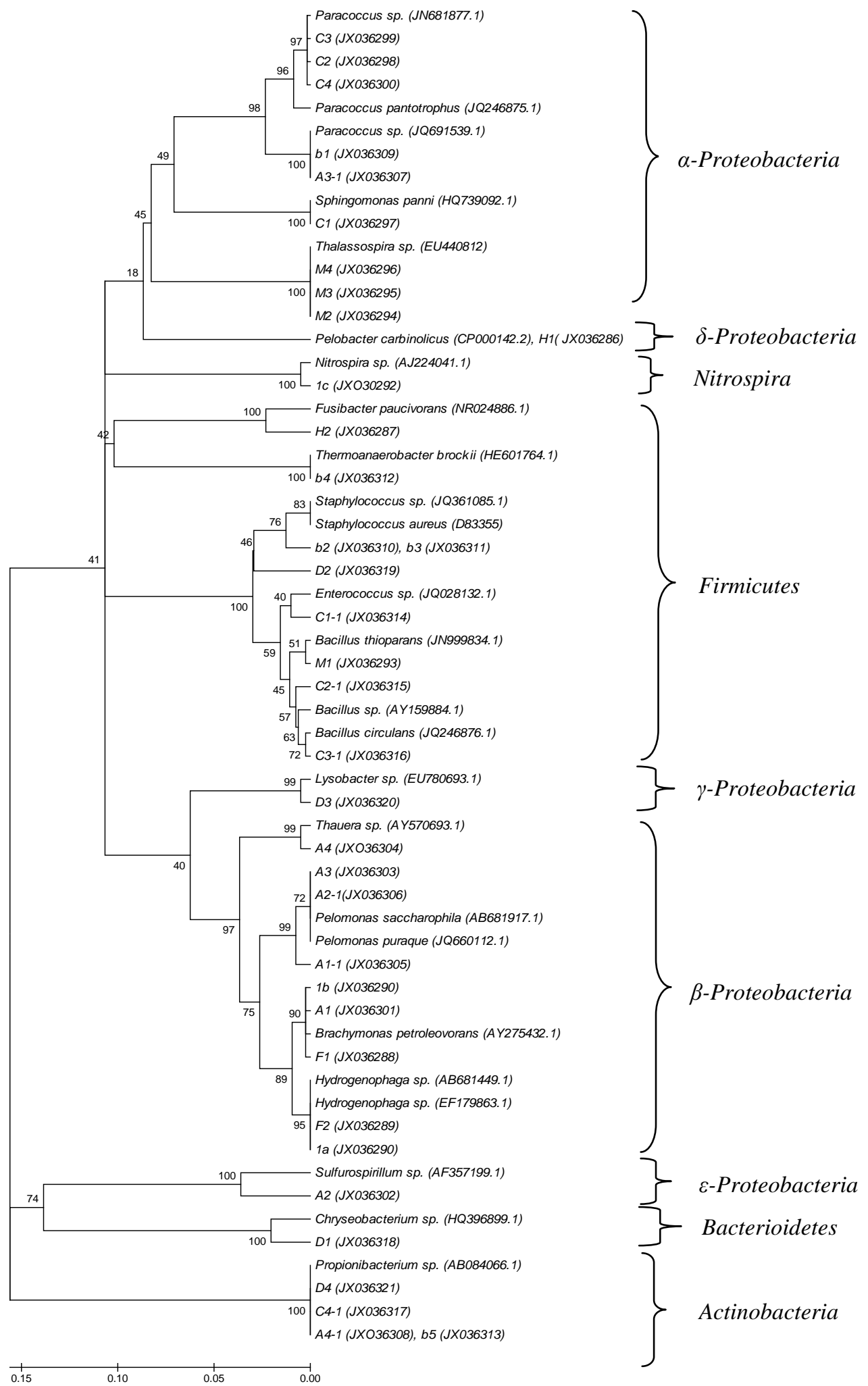


In bacterial community analysis of the Huabei Oilfield China, in a clone library, few OTUs were related to Hydrogenophaga, Sphingomonas and Brachymonas species (Tang et al., 2012). In the study of composition of bacterial communities in oil reservoirs from a southern offshore Brazilian basin, 16S rRNA gene clones were related to the genera Propionibacterium, Bacillus etc. (Sette et al., 2007). Bacterial phylotypes detected by PCR-DGGE of high temperature oil reservoir contained the sequence related to Thermoanaerobacter brockii (Lan et al., 2011). Thauera sp. was reported to be toluene degrader under denitrifying conditions (Van Ham et al., 2003). Staphylococcus aureus, Pseudomonas aeruginosa and Bacillus sp. were isolated from hydrocarbon-polluted site in Ilaje, Ondo state, Nigeria (Boboye et al., 2010). Sequence of sulfate reducing genus Nitrospira was detected in 16S rRNA clone library of Hubei oil field, China (Li et al., 2006). Two novel species of genus Thalosospira were isolated from surface water of waste oil pool (Liu et al., 2007). Sulfurospirillum sp. was isolated from upflow, packed-bed bioreactors inoculated with water produced from an oil field (Hubert and Voordouw, 2007). Paracoccus sp. was isolated from Microcoleus consortium and was able to grow in the extreme conditions such as acid and alkaline $\mathrm{pH}$, high salinity, high and low temperature, and in the presence of petroleum and heavy metals like $\mathrm{Cu}$ and $\mathrm{Pb}$ (Diestra et al., 2007). Pelomonas sp. was found to degrade benzene anaerobically (Weelink, 2008). Carazole degradaing Lysobacter $s p$. was isolated from onshore and freshwater sites (Maeda et al., 2010). As all these bacteria are living in the extreme habitats they are of prime importance in metagenomics study.

In the present study, molecular analysis is used to characterize the diversity of bacterial community in the formation water from petroleum reservoirs of western India. Analysis showed four major bacterial classes: Firmicutes, gamma-proteobacteria, beta-proteobacteria and actinobacteria, revealing a great microbial diversity in these formation water samples. Sequence analysis of excised DGGE bands revealed phylogenetic relationships with $16 \mathrm{~S}$ rRNA gene sequences from many microorganisms previously isolated or identified from petroleum or soil contaminated with petroleum habitats. Further studies are necessary in order to isolate functional bacteria and promote the applications in microbial enhanced oil recovery as well as in bioremediation. Although the level of efforts expended in this study did not profoundly sample the bacterial diversity, we can conclude that it is sufficient to understand the types of bacterial communities in western India oil fields which are otherwise not reported anywhere.

\section{References}

Al-Sharidah, A., Richardt, A., Golecki, J.R., Dierstein R. and Tadros M.H. 2000. Isolation and characterization of two hydrocarbon-degrading Bacillus subtilis strains from oil contaminated soil of Kuwait. Microbiol. Res., 155:157-164.

Atlas, R.M. and Bartha, R. 1998. Microbial ecology: fundamentals and applications. $4^{\text {th }}$ Ed. Addison Wesley Longman, New York: 556-588., ISBN-13: 9780805306552 .

Boboye, B., Olukunle, O. F. and Adetuyi, F.C. 2010. Degradative activity of bacteria isolated from hydrocarbon-polluted site in Ilaje, Ondo State, Nigeria. Afr. J. Microbiol. Res., 4 (23): 2484-2491.

Bonch-Osmolovskaya, E. A., Miroshnichenko, M. L., Lebedinsky, A.V., Chernyh, N. A., Nazina, T.N., Ivoilov, V. S., Belyaev, S. S., Boulygina, E.S., Lysov, Y. P., Perov, A.N., Mirzabekov, A. D., 
Hippe, H., Stackebrandt, E., L'Haridon, S. and Jeanthon, C. 2003. Radioisotopic, culture-based, and oligonucleotide microchip analyses of thermophilic microbial communities in a continental high temperature petroleum reservoir. Appl. Environ. Microbiol., 69(10): 6143-6151.

Bryant, R.S. and Douglas, J. 1988. Evaluation of microbial systems in porous medium for EOR. SPE Reservoir Eng., 3(2): 489-495.

Chitrakoti., M. 2016. Isolation, characterization and description of hydrocarbon degrading Thermophilic Aeribacillus pallidus strain MCM B-882 from oil reservoirs, India. Int. J. Curr. Microbiol. App. Sci., 5(9): 419-430. doi: http://dx.doi.org/10.20546/ijcmas.2016. 509.045

da Cunha, C.D., Rosado, A.S., Sebastián, G.V., Seldin, L. and von der Weid, I. 2006. Oil biodegradation by Bacillus strains isolated from the rock of an oil reservoir located in a deep-water production basin in Brazil. Appl. Microbiol. Biotechnol., 73(4): 949-59.

Dahle. H., Garshol, F., Madsen, M. and Birkeland, N.K. 2008. Microbial community structure analysis of produced water from a high-temperature North Sea oil-field. Antonie van Leeuwenhoek, 93: 37-49.

Diestra, E., Esteve, I., Burnat, M., Maldonado, J. and Sole, A. 2007. Isolation and characterization of a heterotrophic bacterium able to grow in different environmental stress conditions, including crude oil and heavy metals. Communicating Current Research and Educational Topics and Trends in Applied Microbiology. A MendezVilas (Ed) FORMATEX : 90-99.

Eaton, A.D., Clesceri, L.S., Rice, E.W. and Greenberg, A.E. 2005. Standard methods for the examination of water and waste water. $21^{\text {st }}$ Ed. Centennial Edition. APHA, AWWA, WEF.

Ferris, M.J., Muyzer, G. and Ward, D.M.
1996. Denaturing gradient gel electrophoresis profiles of $16 \mathrm{~S}$ rRNAdefined populations inhabiting a hot spring microbial mat community. Appl. Environ. Microbiol., 62(2): 340-346.

Grabowski, A., Nercessian, O., Fayolle, F., Blanchet, D. and Jeanthon, C. 2005. Microbial diversity in production waters of a low temperature biodegraded oil reservoir. FEMS Microbiol. Ecol., 54: 424-433.

Guo, W., Li, D., Tao, Y., Gao, P. and Hu, J. 2008. Isolation and description of a stable carbazole-degrading microbial consortium consisting of Chryseobacterium sp. NCY and Achromobacter sp. NCW. Curr. Microbiol., 57 (3):251-257.

Hubert, C. and Voordouw, G. 2007. Oil Field Souring Control by Nitrate-Reducing Sulfurospirillum spp. that Outcompete Sulfate-Reducing Bacteria for Organic Electron Donors. Appl. Environ. Microbiol., 73 (8): 2644-2652.

Kalish, P.J., Stewart, J.A. and Rogars, W.F. 1964. The effect of bacteria on sandstone permeability, J. Petrol. Technol., 16(7): 805-814.

Kaster, K.M., Bonaunet, K., Berland, H., Kjeilen-Eilertsen, G. and Brakstad, O.G. 2009. Characterisation of cultureindependent and -dependent microbial communities in a high-temperature offshore chalk petroleum reservoir. Antonie van Leeuwenhoek, 96(4): 423439.

Kimura M. 1980. A simple method for estimating evolutionary rate of base substitutions through comparative studies of nucleotide sequences. $J$. Mol. Evol., 16 (20):11-120.

Kotlar, H. Kr., Brakstad, O. G., Markussen, S. and Winnberg, A. 2004. Use of petroleum biotechnology throughout the value chain of an oil company: an integrated approach. In:VazquezDuhalt, Rafael. Petroleum biotechnology developments and perspectives. Author:Vazquez-Duhalt, 
Rafael. ISBN: 9780444516992

Kumar, A., Munjal, A. and Sawhney, R. 2011. Crude oil PAH constitution, degradation pathway and associated bioremediation microflora: an overview. Int J Environ Sci., 1(7): 420-1439.

Lan, G., Li, Z., Zhang, H., Zou, C., Qiao D. and $\mathrm{Cao}$ Yi. 2011. Enrichment and diversity analysis of the thermophilic microbes in a high temperature petroleum reservoir. Afr. J. Microbiol. Res., 5(14):1850-1857.

Li, H., Yang, S.Z., Mu, B.Z., Rong Z.F. and Zhang J. 2006. Molecular analysis of the bacterial community in a continental high-temperature and water-flooded petroleum reservoir. FEMS Microbiol. Lett., 257: 92-98.

Liu, C., Wu, Y., Li, L.,. Ma, Y. and Shao, Z. 2007. Thalassospira xiamenensis sp. nov. and Thalassospira profundimaris sp. nov. Int. J. Syst. Evol. Microbiol., 57(2): 316-320.

Maeda, R., Ito, Y., Iwata, K. and Omori, T. 2010. Comparison of marine and terrestrial carbazole-degrading bacteria. Curr. Res. Educational Topics and Trends in Appl. Microbiol. Microbial Biotechnol., 1311-1321.

Magot, M., Ollivier, B. and Patel, B.K.C. 2000. Microbiology of petroleum reservoirs. Antonie van Leeuwenhoek, 77(2):103-116.

Margaritis, A., Zajic, J.E. and Gerson, D.F. 1979. Production and surface active properties of microbial surfactants. Biotechnol. Bioeng., 21(7):1151-1162.

Ministry of Petroleum and Natural gas, India. Annual report 2015-2016. Available at: http://petroleum.nic.in. Accessed $25^{\text {th }}$ June 2016.

Muyzer, G., de Waal ,E.C. and Uitterlinden, A.G. 1993 Profiling of complex microbial populations by Denaturing Gradient Gel Electrophoresis of polymerase chain reaction-amplified genes coding for $16 \mathrm{~S}$ rRNA. Appl. Environ. Microbiol., 59(3): 695-700.

Nath, S., Deb, B. and Sharma, I. 2012.
Isolation and characterization of cadmium and lead resistant bacteria. Global Adv. Res. J. Microbiol., 1(11): 194-198.

Ochoa-Herrera, V., Leon, G., Banihani, Q., Field, J. A. and Sierra-Alvarez, R. 2011. Toxicity of copper (II) ions to microorganisms in biological wastewater treatment systems. Sci. Total. Environ., 15: 412-413.

Ravot, G., Magot, M., Fardeau, M.L., Patel, B.K., Thomas, P., Garcia, J.L. and Ollivier, B. 1999. Fusibacter paucivorans gen. nov., sp. nov., an anaerobic, thiosulfate-reducing bacterium from an oil-producing well. Int. J. Syst. Bacteriol., 49(3): 1141 1147.

Rawlings, D.E. 1995. Restriction enzyme analysis of 16 rRNA genes for the rapid identification of Thiobacillus ferroxidans, Thiobacillus thiooxidans and Leptospirillum ferrooxidans strains in leaching environments. Biohydrometallurgical Processing pp. 917. In: Jerez, C.A, T. Vargas, H. Toledo, J.V. Wiertz (ed.), Biohydrometallurgical processing, vol. II. University of Chile Press, Santiago, Chile (1995).

Rouviere, P.E. and Chen, M.W. 2003. Isolation of Brachymonas petroleovorans $\mathrm{CHX}, \mathrm{a}$ novel cyclohexane-degrading $\quad \beta$ proteobacterium. FEMS Microbiol. Lett., 227: 101-106.

Saitou, N. and Nei, M. 1987. The neighborjoining method: a new method for reconstructing phylogenetic trees. Mol. Biol. Evol., 4(4): 406-425.

Sambrook, J. and Russell, D.W. 2001. Molecular cloning - a laboratory manual, 3rd ed., Cold Spring Harbor Laboratory Press, Cold Spring Harbor.

Schafer, H. and Muyzer, G. 2001. Denaturing gradient gel electrophoresis in marine microbial ecology. Methods Microbiol., 30: 425-468.

Schwieger, F. and Tebbe, C.T. 1998. A new approach to utilized PCR-single-strand- 
conformation polymorphism for $16 \mathrm{~S}$ rRNA gene-based microbial community analysis. Appl. Environ. Microbiol., 64(12): 4870-4876.

Sette, L.D., Simioni, K.C., Vasconcellos, S.P., Dussan, L.J., Neto E.V., and. Oliveira V.M. 2007. Analysis of the composition of bacterial communities in oil reservoirs from a southern offshore Brazilian basin. Antonie van Leeuwenhoek, 91(3): 253-266.

Stackebrandt, E. and Goebel, B.M. 1994. Taxonomic note: a place for DNADNA reassociation and $16 \mathrm{~S}$ rRNA sequence analysis in the present species definition in bacteriology. Int. J. Syst. Bacteriol., 44(4): 846-849.

Tang, Y.Q., Li, Y., Zhao, J.Y., Chi, C.Q., Huang, L.X., Dong H.P. and Wu, X.L. 2012. Microbial Communities in LongTerm, Water-Flooded Petroleum Reservoirs with Different in situ Temperatures in the Huabei Oilfield, China. PLOS ONE, 7, e33535. doi:10.1371/journal.pone.0033535

Thompson, J.D., Gibson, T.J., Plewniak, F., Jeanmougin F. and Higgins D.G. 1997. The ClustalX windows interface:flexible strategies for multiple sequence alignment aided by quality analysis tools. Nucleic Acids Res., 25(24): 48764882.

Van Hamme, J.D., Singh, A. and Ward, O.P. 2003. Recent Advances in Petroleum
Microbiology. Microbiol. Mol. Biol. Rev., 67(4): 503-549.

Voordouw, G., Armstrong, S.M., Reimer, M. F., Fouts, B., Telang, A.J., Shen, Y., and Gevertz, D. 1996. Characterization of 16S rRNA genes from oilfield microbial communities indicates the presence of a variety of sulfate-reducing, fermentative, and sulfide-oxidizing bacteria. Appl. Environ. Microbiol., 62(5): 1623-1629.

Voordouw, G., Voordouw, J. K., Jack, T. R., Foght, J., Fedorak, P. M., and Westlake, D.W.S. 1992. Identification of distinct communities of sulfate-reducing bacteria in oilfields by reverse sample genome probing. Appl. Environ. Microbiol., 58(11): 3542-3552.

Wang, J., Ma, T., Zhao, L., Lv, J., Li, G., Liang, F. and Liu, R. 2008. PCR-DGGE method for analyzing the bacterial community in a high temperature petroleum reservoir. World J Microbiol Biotechnol., 24 (9):1981-1987.

Weelink, S.A.B. 2008. Degrdation of benzene and other aromatic hydrocarbons by anaerobic bacteria. $\mathrm{PhD}$ thesis Wageningen University, Wageningen, The Netherlands.

Zhou, J., Bruns, M.A. and Tiedje, J.M. 1996. DNA Recovery from Soils of Diverse Composition. Appl. Environ. Microbiol., 62(2): 316-322.

\section{How to cite this article:}

Mahesh Chitrakoti and Kalpana Chandramore. 2016. Phylogenetic Diversity of Bacterial Communities of Western India Oil Fields by PCR-DGGE. Int.J.Curr.Microbiol.App.Sci. 5(11): 357-370. doi: http://dx.doi.org/10.20546/ijcmas.2016.511.041 